\title{
SACRED GROVES IN CONSERVATION OF BIODIVERSITY IN ODISHA
}

\author{
Taranisen Panda*, Nirlipta Mishra ${ }^{* *}$, Bikram K. Pradhan", Shaik Rahimuddin ${ }^{* *}$, \\ Rajballav Mohanty ${ }^{* * *}$
}

* Chandbali College, Department of Botany, Chandbali, Bhadrak, Odisha, India

${ }^{* *}$ Chandbali College, Department of Zoology, Chandbali, Bhadrak, Odisha, India

*** Ex-Reader in Botany, Plot No. 1311/7628, Satya Vihar, Rasulgarh, Bhubaneswar, Odisha, India

corresponding author: Taranisen Panda, e-mail: taranisenpanda@yahoo.co.in

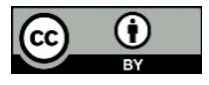

This work is licensed under a

Creative Commons Attribution 4.0

$\underline{\text { International License }}$
Professional paper

Received: September $12^{\text {th }}, 2019$

Accepted: October $29^{\text {th }}, 2019$

HAE-1920

https://doi.org/10.33765/thate.10.1.2

\begin{abstract}
Phytodiversity survey of sacred groves was carried out for a period of two years (2016-2018) in Bhadrak district of Odisha, India. A total of 42 plant species belonging to 39 genera under 26 families are recorded from 20 selected sacred groves of the district. Moraceae represents the dominant family. The respondents affirmed that the plants inside these sites are never cut or harmed and some plant like neem (Azadirachta indica A. Juss.), banyan (Ficus benghalensis L.) and peepal (Ficus religiosa L.) present in the sacred groves are more than a century old. The present study indicates the role of sacred groves in biodiversity conservation through faith, belief, religious activity and community participation.
\end{abstract}

Keywords: biodiversity, deity, cultural and religious belief, traditional knowledge

\section{INTRODUCTION}

Biodiversity is rich at many places in India beyond the designated officially protected areas due to some religious beliefs and taboos [1]. Taboos are the unwritten, orally transmitted social rules that regulate human behaviour [2] and play a major role for the conservation of natural resources, species, and ecosystems on a local and regional level [3]. Traditional customs and beliefs of human society in the form of nature worship have played an important role in protection and conservation of biodiversity worldwide $[4,5]$.
Sacred groves are patches of forest or places with natural vegetation conserved through man's spiritual beliefs and faith [6], being considered holy or sacred place with existence of the village deity there. Nobody disrupts the vegetation or cuts trees from inside for the fear of the divine curse. Many plant and animal species inhabit these protected sites due to lack of human interference rather due to community protection [7, 8]. These sacred groves naturally are rich sources of rare and endemic plants of the concerned region [9, $10]$. Even in some cases, it is considered as a mini biosphere reserve [11]. The importance 
of sacred groves is now well realized and even in IUCN's (International Union for Conservation of Nature) six protected categories, cultural and spiritual values are better reflected [12]. There are several studies carried out in different parts of the country [13-15] to assess the role of sacred groves in conservation of flora of the concerned region. But there is hardly any study and exploration on such sites in Odisha. So, the present study was planned and executed during 2016 - 2018 to explore and evaluate the role of sacred groves in Bhadrak district of Odisha, India. The current work may be helpful to understand the ancient vegetation history including the predominant flora, which would be very significant in environmental development through better management of the groves and to create conducive conditions for restoration and sustenance of wild biodiversity through community participation.

\section{EXPERIMENTAL}

\section{Study site}

Bhadrak district $\left(20^{\circ} \quad 43^{\prime}-21^{\circ} \quad 13^{\prime} \mathrm{N}\right.$ and $86^{\circ}$ $\left.6^{\prime}-87^{\circ} \mathrm{E}\right)$ is in Northeast Odisha. It spreads over $2505 \mathrm{~km}^{2}$ and has 1,506,522 inhabitants (2011 Census). Four other districts - Balasore, Kendrapara, Jajpur, and Koenjher - surround Bhadrak district while a part is bounded by the Bay of Bengal. The district covers about 1.61 $\%$ of the total land area of the state and contributes $3.59 \%$ of the state's population. About $86.66 \%$ of the inhabitants are villagers and the people are engaged in agricultural practices as their primary occupation. Paddy is grown as the main crop in Kharif, covering approximately $94 \%$ of the total cultivable area. In addition to cultivation, people in the seacoast area (Dhamara, Chudamani and Chandabali) also depend upon fishing for their livelihood. The climate of this district is generally hot and humid with May being the hottest month. December is the coldest month with monsoon generally arriving during the month of June. The rainfall during June to October constitutes at least $75 \%$ of the actual rainfall of this district. Being situated near Bay of Bengal, the district is characterized by periodic earth tremors, thunderstorms in the rains and dust storms in April and May.

\section{Data collection}

The methods employed in this study were designed with the purpose of providing base line information on the biodiversity of sacred groves and funeral ground, through literature survey and field visits to various areas (seven blocks of the district i.e. Basudevpur, Bhadrak, Bhandaripokhari, Bonth, Chandbali, Dhamnagar and Tihidi) from June 2016 to May 2018 in Bhadrak district, Odisha, India. Systematic field surveys were carried out monthly, following established and standard procedures [16]. The information on plant biodiversity was obtained through structured questionnaires, complemented by free interviews and informal conversations [16, 17]. During these surveys, 20 sacred groves were covered for preparing an inventory of tree and shrub species of angiosperms. Only tree and shrub species were considered as the ground was disturbed by domestic herbivores like cattle, goat, sheep etc. A total of 75 respondents (village priest and other elderly persons) were considered the key informants in the study, and the selection process was based on the knowledge and experience in sacred groves. The information on historical background of groves and their associated deity, nature of vegetation, largest trees present in it, age of trees, rituals, cultures and taboos were collected from ethnic communities. Personal interviews and group discussions carried out in the local language revealed specific information about the plants, which were further compared and authenticated by crosschecking [18]. The plant specimens were identified during the field study. Sample specimens of confusing species were collected and identified with the help of flora book [19]. 


\section{RESULTS AND DISCUSSION}

There was presence of a sacred grove in each village, usually in the middle or end of the village. It was believed to be the abode of certain deity, worshiped by the village priest. People had adopted strict rules of not cutting any trees, no grazing of herbivores, and no killing of animals inside the groves, believing such place and specifically the trees to be the abode of god and ancestral spirits. Different rituals and religious functions were performed inside the site for the wellbeing of the villagers, their animals, crops, and protection against diseases. A total of 42 plant species belonging to 39 genera under 26 families with different life forms (trees and shrubs) were identified during the survey. Members of family Moraceae ( $5 \mathrm{spp}$.) were found to be the most represented among all the species identified followed by Caesalpiniaceae (4 sp.) and Fabaceae (3sp.) respectively. Seven families were represented by two species and 16 were monospecific of the total number families in the inventory (Table 1, Figure 1 and 2). Different species of Ficus were predominantly present in most of the sites in terms of generic richness. These species provide a niche for the large number of birds and small animals to feed and live there undisturbed. Some ornamental plants as well as plants required in rituals and worship were found to be naturally-occurring in these premises.

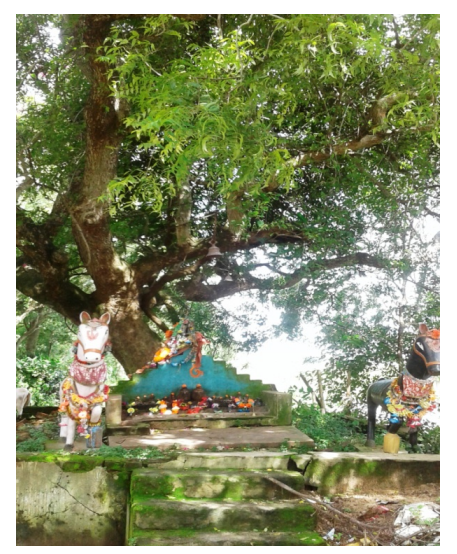

Figure 1. Neem tree with village deity

Indigenous communities in India have cultural and religious beliefs and have worshiped trees since time immemorial. This religious belief serves as an instrument for protection of rare plant species [20]. Every sacred grove has own legends, lore, and myths that link between the present and past society in terms of biodiversity, culture, religious and ethnic belief [21]. It represents an excellent example of traditional conservation practice that continues to provide respite to the dwindling bio-resources in different parts of the world, predominantly in tropical Asia, Africa, South America and Australia [22 - 27]. They have also been reported from different parts of India [28] and found mainly in tribal localities. Prohibition of killing animals and cuttingdown trees, except when wood is needed for the religious purposes like construction and repair of temple buildings, and temple rituals in the sacred groves of Bhadrak district substantiate the findings of earlier studies [22, 29]. The dominance of genus Ficus in sacred groves of the study area is also reported [30]. In the present investigation, Ficus benghalensis L. and Ficus religiosa L. provide a niche for large number of small animals. These species are classified as "keystone mutualist" for the maintenance of tropical biological diversity $[31,32]$.

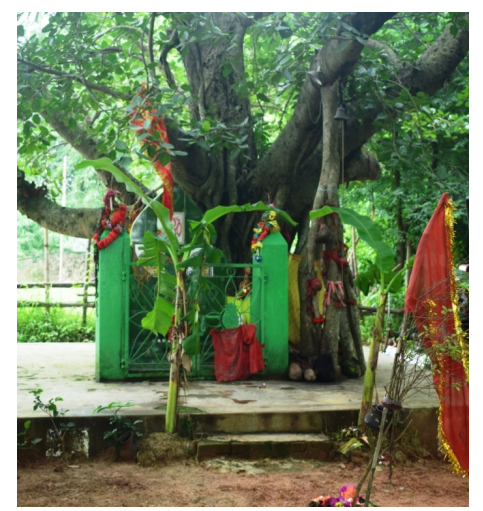

Figure 2. Banyan tree with village deity

All the sites visited in Bhadrak district of Odisha show various level of depletion due to anthropogenic and other allied activities. As reported by elderly villagers, most of these plant species were predominantly growing in the past, which have now vanished from the surrounding locality due to such interference. The area and vegetation of sacred groves are rapidly shrinking due to above biotic pressure. It is akin to the status of majority of sacred groves in other parts of the country [33]. 
Table1. Plant species recorded from selected sacred groves of Bhadrak district, Odisha

\begin{tabular}{|c|c|c|c|}
\hline & Local Name & Botanical Name & Family \\
\hline 1. & Kaincha & Abrus precatorius L. & Fabaceae \\
\hline 2. & Bana Ritha & Acacia sinuata (Lour.) Merr. & Mimosaceae \\
\hline 3. & Bela & Aegle marmelos L. & Rutaceae \\
\hline 4. & Kadamba & Anathocephalus cadamba Roxb. & Rubiaceae \\
\hline 5. & Jeuta & Artocarpus lacucha Roxb. & Moraceae \\
\hline 6. & Karamanga & Averrhoa carambola $\mathrm{L}$. & Geraniaceae \\
\hline 7. & Nima & Azadirachta indica A. Juss & Meliaceae \\
\hline 8. & KantaBaunsa & Bambusa bambos L. Voss & Poaceae \\
\hline 9. & Kanchana & Bauhinia retusa Roxb. & Caesalpiniaceae \\
\hline 10. & Simili & Bombax ceiba L. & Bombacaceae \\
\hline 11. & Tala & Borassus flavelifer $\mathrm{L}$. & Arecaceae \\
\hline 12. & Gila & Caesalpinia bonduc L. & Caesalpiniaceae \\
\hline 13. & Beta & Calamus guruba Buch. & Arecaceae \\
\hline 14. & Pulanga & Calophyllum inophyllium L. & Clusiaceae \\
\hline 15. & Arakha & Calotropis procera (Ait.) R. Br. & Asclepiadaceae \\
\hline 16. & Baruna & Crateva magna Lour. & Capparidaceae \\
\hline 17. & Kala Dudura & Darura metel L. & Solanaceae \\
\hline 18. & Oau & Dillenia indica L. & Dilleniaceae \\
\hline 19. & Kendu & Diospyrus melanoxylon Roxb. & Ebenaceae \\
\hline 20. & Aonla & Emblica officinalis Gaertn. & Euphorbiaceae \\
\hline 21. & Paladhua & Erythrina variegata L. & Fabaceae \\
\hline 22. & Kaitha & Feronia limonia $\mathrm{L}$. & Rutaceae \\
\hline 23. & Bara & Ficus benghalensis L. & Moraceae \\
\hline 24. & Dimiri & Ficus racemosa L. & Moraceae \\
\hline 25. & Aswastha & Ficus religiosa L. & Moraceae \\
\hline 26. & Amba & Mangifera indica $\mathrm{L}$. & Anacardiaceae \\
\hline 27. & Baula & Mimusops elengi L. & Sapotaceae \\
\hline 28. & Singadahara & Nyctanthes arbortritis L. & Oleaceae \\
\hline 29. & Durlava & Ocimum basilicum L. & Lamiaceae \\
\hline 30. & Tulsi & Ocimum sanctum L. & Lamiaceae \\
\hline 31. & Kia & Pandanus fascicularis Lam. & Pandanaceae \\
\hline 32. & Jandakhai & Phyllanthus reticulatus Poir. & Euphorbiaceae \\
\hline 33. & Katha Champa & Plumeria rubra $\mathrm{L}$. & Apocynaceae \\
\hline 34. & Karanja & Pongamia pinnata $\mathrm{L}$. & Fabaceae \\
\hline 35. & Patala Garuda & Rauvolfia serpentina (L.) Benth. ex. Kurz. & Apocynaceae \\
\hline 36. & Chakunda & Samawea saman Merr. & Mimosoceae \\
\hline 37. & Ashoka & Saraca asoca Roxb. & Caesalpiniaceae \\
\hline 38. & Ambada & Spondias pinnata Kurz. & Anacardiaceae \\
\hline 39. & Sahada & Streblus asper Lour. & Moraceae \\
\hline 40. & Kochila & Strychnos nux-vomica L. & Loganiaceae \\
\hline 41. & Jamu & Syzygium cumini L. & Myrtaceae \\
\hline 42. & Tentuli & Tamarindus indica L. & Caesalpiniaceae \\
\hline
\end{tabular}




\section{CONCLUSION}

Our study demonstrates the importance of sacred groves in protecting and conserving various life forms. As the sacred groves surveyed have been observed to become the victims of exploitation at different levels, suitable remedial measures like awareness programme and formation as well as implementation of some legal guidelines are warranted for protection of such mini biosphere reserves in Bhadrak district of Odisha. Moreover, there should be further indepth study in wider scale covering larger areas of the state to pinpoint the status of sacred groves and the threatened, endangered or near extinct species, if any, which once dominated the concerned region.

\section{REFERENCES}

[1] A.K. Jain, V.V. Wagh, C. Kadel, Conservation status of some miniature sacred groves in Jhabua dist. (M.P.), Ethnobotany 23(2011), 106-115.

[2] J. Colding, C. Folke, The relations among threatened species, their protection, and taboos, Conservation Ecology 1(1997) 1, 1-11.

[3] M. Gadgil, F. Berkes, C. Folke, Indigenous knowledge for biodiversity conservation, Ambio 22(1993), 151-156.

[4] K. Upadhaya, H.N. Pandey, P.S. Law, R.S. Tripathi, Tree diversity in sacred groves of the Jaintia hills in Meghalaya Northeast India, Biodiversity and Conservation 12(2003), 583-597.

[5] S.A. Bhagwat, C. Rutte, Sacred groves: potential for biodiversity management, Frontiers in Ecology and Environment 4(2006), 519-524.

[6] S.S. Dash, Kabi sacred grove of north Sikkim, Current Science 89(2005) 3, 427-428.

[7] S. Sukumaran, S. Jeeva, A floristic study on miniature sacred forests at Agastheeshwaram, southern peninsular India, EurAsian Journal of Biosciences 2(2008), 66-78.
[8] R. Ray, T.V. Ramachandra, Small sacred groves in local landscape: are they really for conservation, Current Science 98(2010) 9, 1178-1180.

[9] R.H. Whittaker, Communities and Ecosystems, Mac Millan publishing company, New York, 1975.

[10] S. Jeeva, B.P. Mishra, N. Venugopal, L. Kharlukhi, R.C. Laloo, Traditional knowledge and biodiversity conservation in the sacred groves of Meghalaya, Indian Journal of Traditional Knowledge 5(2006), 563-568.

[11] M. Gadgil, V.D. Vartak, Sacred groves of Maharashtra: an inventory, In: Glimpses of Indian Ethnobotany, ed. S.K. Jain, Oxford and IBH Publishing, New Delhi, 1981, 279-294.

[12] IUCN, World commission on protected areas task force on protected area categories, one of a series of papers for the IUCN Categories Summit, Andalusia, Spain, 2007.

[13] M. Amirthalingam, Sacred groves of India - An overview, International Journal of Current Research in Biosciences and Plant Biology 3(2016) 4, 64-74.

[14] S. Manna, S. Manna, T.K. Ghora, A. Roy, Sacred grove as remnant forest: A vegetation analysis, Biodiversitas 18(2017) 3, 899-908.

[15] S. Trivedi, E. Bharucha, R. Mungikar, Rapid assessment of sacred groves: a biodiversity assessment tool for ground level practitioners, Journal of Threatened Taxa 10(2018) 2, 11262-11270.

[16] G.J. Martin, Ethnobotany: A Methods Manual, Chapman and Hall, London, 1995.

[17] H.P. Huntington, Using traditional ecological knowledge in science: methods and applications, Ecological Applications 10(2000) 5, 1270-1274.

[18] A.B. Cunningham, Applied ethnobotany: People, wild plant use and conservation, Earth scan Publishing Ltd., London, 2001.

[19] H.O. Saxena, M. Brahmam, The Flora of Orissa (Vol. I-IV), Forest development corporation, Bhubaneswar: Orissa, 1996. 
[20] H.N. Pandey, O.P. Tripathi, R.S. Tripathi, Ecological analysis of forest vegetation of Meghalaya, In: Approaches for Increasing Agriculture Productivity in Hill and Mountain Ecosystem, eds. B.P. Bhatt, K.M. Bujarbaruah, Y.P. Sharma, Patiram, ICAR Research Complex for NEH Region, Umain, Meghalaya, 2003, 3739.

[21] M.L. Khan, A D. Khumbongmayum, R.S. Tripathy, The sacred groves and their significance in conserving biodiversity - An overview, International Journal of Ecology and Environmental Science 34(2008) 4, 277-291.

[22] J.D. Hughes, M.D.S. Chandran, Sacred groves around the earth: an overview, In: Conserving the sacred for biodiversity management, eds. P.S. Ramakrishnan, K.G. Saxena \& U.M. Chandrasekhar, UNESCO and Oxford-IBH Publishing, New Delhi, 1998, 69-86.

[23] V. Agbo, N. Sokpon, Sacred groves as tools for indigenous forest management in Benin, Annales des sciences Agronomiques du Benin 2(1999), 161175.

[24] S. Appiah-Opoku, Indigenous beliefs and environmental Stewardship: a rural Ghana experience, Journal of Cultural Geography 2(2007) 2, 79-98.

[25] R. Ray, Developing strategies for conservation of threatened endemic biodiversity of the sacred groves of Central Western Ghats, project report, Centre for Ecological sciences, Indian Institute of science, Bangalore, 2011.

[26] C.L. Cardelus, P. Scull, J. Hair, M. Baimas-George, M.D. Lowman, A.W. Eshet, A preliminary assessment of Ethiopian sacred grove status at the landscape and ecosystem scales, Diversity 5(2013), 320-334.

[27] O.M. Agbogidi, E.E. Benson, Potential role of sacred groves in the maintenance of biodiversity, World Journal of Biology and Medical Sciences 1(2014) 4, 40-48.

[28] K.C. Malhotra, Y. Gokhale, S. Chatterjee, Cultural and ecological dimensions of sacred groves in India. Indian National Science Academy, New Delhi, 2001.

[29] M.L. Khan, J.P.N. Rai, R.S. Tripathi, Population structure of some tree species in disturbed and protected sub-tropical forests of north-east India, Acta Ecologica 8(1987) 3, 247-255.

[30] M. Gadgil, G. Utkarsh, P. Pramod, Genus Ficus - Trees of Life, The Hindu Survey Environment 1996, 171-175.

[31] J. Terborgh, Keystone plant resources in the tropical forest, In: Conservation biology, eds. I. Soulé, E. Michael, Sinauer, Sunderland, Massachusetts, USA, 1986, 330-344.

[32] J.E.D. Oliver King, C. Viji, D. Narasimhan, Sacred groves: Traditional ecological heritage, International Journal of Ecology and Environmental Sciences 23(1997), 463-470.

[33] M.J. Bhandary, K.R. Chandrasekhar, Sacred groves of Dakhina Kanada and Udupi districts of Karnataka, Current Science 85(2003), 1655-1656.

\section{Acknowledgements}

The authors express their gratitude to the villagers as well as informants who shared their knowledge during the field study and to the college authority as well as administrative and revenue officials for their permission to carry out the work successfully. 